\title{
Antidumping Mechanisms and
}

\author{
Safeguards in Peru
}

Richard Webb*

Josefina Camminati

Raúl León Thorne

World Bank Policy Research Working Paper 3658, July 2005

The Policy Research Working Paper Series disseminates the findings of work in progress to encourage the exchange of ideas about development issues. An objective of the series is to get the findings out quickly, even if the presentations are less than fully polished. The papers carry the names of the authors and should be cited accordingly. The findings, interpretations, and conclusions expressed in this paper are entirely those of the authors. They do not necessarily represent the view of the World Bank, its Executive Directors, or the countries they represent. Policy Research Working Papers are available online at http://econ.worldbank.org.

\footnotetext{
* Director of the Economic Research Center, University of San Martín de Porres Email: richardwebb@terra.com.pe
}

The authors would like to acknowledge the assistance of, Roberto Abusada, Mercedes Araoz, Carlos Carrillo, José Ezeta, Cristy García Godos, Ludwig Meier, Jorge Muñiz, Gastón Pacheco, Patricia Teullet, and the Technical Secretariat of the Antidumping and Subsidies Commission, INDECOPI, for their collaboration in the preparation of this report. The authors would also like to acknowledge the valuable comments made by their colleagues Diana Tussie, Elías Bacarat, J. Michael Finger and Julio J. Nogués in May 2004 at the Workshop held in Buenos Aires on "The Use of Safeguards and Antidumping in Latin America". 


\section{Antidumping Mechanisms and Safeguards in Peru, by Richard Webb, Josefina Camminati and Raúl León Thorne}

Peru's experience in the application of antidumping and safeguard measures is characterized by a radical change in the philosophy and procedures of trade at the beginning of the 1990s, and by an increasing use of these mechanisms. Trade liberalization was accompanied by the liberalization of foreign currency transactions and of financial and labor markets. Also, the internal revenue administration was modernized, institutions for regulation and competition defense were created, and state enterprises were transferred to private owners or concessionaires. New laws and institutions were created to regulate markets, including INDECOPI, a novel government agency charged with anti-monopoly regulation and consumer defense, and which houses the Antidumping and Subsidies Commission. This highly autonomous and technical Commission became the central player in the implementation of WTO rules and procedures for fair trade.

Since the reform was launched, a total of 81 trade protection cases have been presented, of which 57 were followed by a dumping investigation. The application of antidumping duties was approved for 29 of the cases investigated. Only two cases of safeguard investigations were recorded, one of which (Chinese textile clothing articles) is still in the negotiation phase.

This paper reviews that case experience in detail, concluding that Peru has clearly differentiated between unfair competition and dumping on the one hand, and damage and safeguards on the other, and has applied strict technical criteria to the former and broader political considerations to the latter. Despite recent indications of a partial retreat from those principles, the decade-old reform is expected to last. 


\section{Table of Contents}

\section{Peru's Trade Policy}
(a) Evolution
(b) Economic and Political Context of Liberalization
(c) Immediate Background of the 1990 Reform
(d) The New Economic Policy
(e) The New Foreign Trade Policy

\section{Antidumping and Safeguards}

\section{A. Institutional Reform}

\section{INDECOPI}

2. The Antidumping and Subsidies Commission (CDS)

3. Rules and Procedures

(a) Antidumping Rules and Procedures

(b) Safeguard Rules and Procedures

4. Other Aspects of Peru's Experience

\section{B. Peru's Cases}

\section{Overall Results}
(a) Outcomes of Investigation Requests
(b) Incidence over Time
(c) Incidence by Sectors
(d) Incidence by Country
(e) Average Length of Processes
(f) Andean Community Cases
(g) Safeguard Cases
(h) Appeals

\section{Special Cases}
A. Cast Steel Balls: Chile
B. Cornstarch and Glucose Syrup: Mexico
C. Textile Clothing Articles: China

Conclusions

Bibliography 


\section{Peru's Trade Policy}

The history of Peru's trade policy has been characterized by an uninterrupted pendular movement, with cycles that responded to the macroeconomic context, and increasingly, to the influence of pressure groups and ideologies.

\section{(a) Evolution}

At the outset of republican history (1820-1840), fiscal requirements of the newly installed government led to a period of high tariffs. This was followed by a long liberal period (1840-1880), in the context of fiscal and balance of payments abundance made possible by a guano export boom. But when it collapsed and Peru was defeated in the War of the Pacific (1880-1990), protectionism became the predominant policy again, with two distinct interruptions.

The return to liberal policies in 1948 was part of an adjustment program supported by the recovery of exports and direct foreign investments. Nevertheless, during the following two decades, the pressure of protectionist ideas and industrial lobbies gradually eroded this liberalization and the country recorded the period of greatest manufacturing dynamism. In 1959, an Industrial Promotion Law was passed, which contributed to higher protection through subsidy policies and preferential treatment for the sector.

With the arrival in 1968 of a military government strongly influenced by the Economic Commission for Latin America and the Caribbean (ECLAC), the protectionist trend became radicalized, mainly for ideological reasons. In the following decade, paratariff measures were multiplied, the imports of products manufactured in the country were banned, tariffs rose, and a severe exchange rate control was imposed, producing an extreme degree of protectionism.

Then, the military government itself went back to liberalization as part of the new adjustment program, on account of the severe macro-economic and balance of payment crisis. All para-tariff measures were removed and tariffs were reduced. This policy continued in 1980-1982, under the new democratic government.

This return to liberalization aborted in 1983 when the external debt crisis and El Niño storm brought new problems to the balance of payments and employment, of which the industrial lobby took advantage of. Between 1985 and1990, the new government led by APRA, a social-democratic party, restored several para-tariff and tariff

measures, and created an additional degree of effective protection through a multiple exchange rates scheme.

In 1990, both a new government and a severe adjustment program -due to the political crisis generated by inflation, recession, lack of foreign currency and terrorism- marked the beginning of economic liberalization. 


\section{(b) Economic and Political Context of the Liberalization}

Antidumping mechanisms and safeguards were part of an exceptionally profound liberal reform imposed by Alberto Fujimori's government since July 1990.

Fujimori became president in the context of one of the most severe economic and political crises of the country. The economy had experienced hyperinflation during the two preceding years, while domestic production collapsed by $20 \%$ and public expenditure decreased even more due to the fall in revenue collection and the loss of the government's credit capacity. The presence of the state in the national territory was strongly reduced due to fiscal impoverishment, corruption and growing terrorism led by Sendero Luminoso (Shining Path) and MRTA ${ }^{1}$. In general, quantity and quality of education, public health services, justice, police protection and other services of the state declined severely.

This collapse was attributed to APRA, the governing party since 1985. Toward 1990, terrorism had extended to most of Peru's territory and represented a real threat to the survival of democracy. This danger, along with the loss of popularity of interventionist, pro-state ideologies, opened the door to an extreme reaction in favor of liberal ideas.

During the electoral campaign of 1990, candidate Vargas Llosa's liberal message was no longer regarded as a rationalization for big business and became instead a legitimate argument in favor of the national interest. Paradoxically, Fujimori was not elected on a liberal platform, but his lack of political ties or debts, his practical way of perceiving things, and the situation of emergency led him into the liberal path.

(c) Immediate Background of the 1990 Reform

The import substitution policy was based on a tariff structure characterized by a high average tariff level and high dispersion. There were more than 56 different tariff levels from $10 \%$ to $84 \%$, which, combined with diverse exonerations, generated a varied protection structure. The simple tariff average was $66 \%$ and the weighted average was $44 \%$.

Additionally, 535 items were restricted and around $540-23 \%$ of the industrial production- were on the Banned Imports List.

\footnotetext{
${ }^{1}$ Tupac Amaru Revolutionary Movement.
} 


\section{Table 1. Para-tariff Restrictions}

\begin{tabular}{|l|r|r|r|r|}
\hline Items & July 1985 & Dec 1988 & Dec 1989 & Dec 1990 \\
\hline Free & 4,757 & 0 & 4,192 & 5269 \\
\hline Restricted & 350 & 4,724 & 535 & 0 \\
\hline Banned & 196 & 539 & 539 & 0 \\
\hline
\end{tabular}

Source: BCRP

The tariff structure generated extreme positive and negative levels of effective protection. Effective protection was $261 \%$ for articles of clothing, $189 \%$ for dairy products and $134 \%$ for shoes. Several primary and export sectors faced negative effective protection.

Sector officials made the decisions on tariffs and the inclusion or exclusion of products in the lists of banned or restricted imports, while the Central Bank assigned the exchange rates applicable to each import item. There was no unified autonomous technical authority to review protection or no protection requests and to ensure uniform criteria and minimal political interference. In practice, the high level of official discretion contributed to uncertainty, inefficiency and corruption.

\section{(d) The New Economic Policy}

From its outset, the new government enforced an aggressive structural reform program to liberalize markets.

The early measures focused on eliminating hyperinflation. In August 1990, a "shock" adjustment was made to rapidly set controlled prices free, removed almost all subsidies, launched a programmed reduction in monetary expansion, and established a managed floating exchange rate. Inflation was substantially reduced in 1991, even when the instant death experimented by other hyperinflations did not take place.

In spite of the emphasis on stabilization, structural changes that became the framework for trade reform were launched in 1990. 


\begin{tabular}{|c|c|c|}
\hline Stabilization & $\begin{array}{l}1990- \\
1993\end{array}$ & $\begin{array}{l}\text { Price subsidies eliminated. } \\
\text { Unified floating exchange rate. } \\
\text { Monetary expansion reduced. } \\
\text { New Central Bank Law. }\end{array}$ \\
\hline Tax & $\begin{array}{l}1990- \\
1992\end{array}$ & The tax structure reduced and simplified. \\
\hline Foreign Trade & $\begin{array}{l}1990- \\
1992\end{array}$ & $\begin{array}{l}\text { Tariff level and dispersion reduced. } \\
\text { Prohibitions, para-tariff measures and state import } \\
\text { monopolies eliminated. Exemptions reduced. } \\
\text { Customs strengthened. }\end{array}$ \\
\hline Financial & $\begin{array}{l}1990- \\
1996\end{array}$ & $\begin{array}{l}\text { Capital flows and foreign currencies are freed. } \\
\text { Stock exchange reforms launched. } \\
\text { New law for Banks and Banks and creation of Banking } \\
\text { and Insurance Superintendency. Deposit Insurance Fund } \\
\text { created. } \\
\text { First-tier banking prohibited for the State. } \\
\text { A private pension system created. }\end{array}$ \\
\hline Privatization & $\begin{array}{l}\text { 1991- } \\
1992\end{array}$ & $\begin{array}{l}\mathrm{COPRI}^{2} \text { and } \mathrm{CEPRI}^{3} \text { s created. } \\
\text { Auctions launched. } \\
\text { Autonomous regulating entities and INDECOPI }{ }^{4} \text { created. }\end{array}$ \\
\hline Labor & $\begin{array}{l}1990- \\
1997\end{array}$ & $\begin{array}{l}\text { Labor market deregulated and flexibilized. } \\
\text { Labor stability partially eliminated, including a change in } \\
\text { the Constitution. } \\
\text { Payroll taxes reduced. }\end{array}$ \\
\hline $\begin{array}{l}\text { State Deregulation } \\
\text { and Reduction }\end{array}$ & $\begin{array}{l}1990- \\
1996\end{array}$ & $\begin{array}{l}\text { Regulations and processes streamlined. } \\
\text { State workers reduced. }\end{array}$ \\
\hline Social & $\begin{array}{l}1991- \\
1998\end{array}$ & $\begin{array}{l}\text { Social programs created. } \\
\text { Poverty targeted. }\end{array}$ \\
\hline
\end{tabular}

The reform was conceived as an organic set of measures that mutually reinforced one another. Long-term institutional changes were required to ensure its sustainability. The main goal of reform was to promote and flexibilize the market economy. The following actions were taken; foreign trade and foreign currency were liberalized, financial and labor markets were also liberalized, the internal revenue administration was modernized, institutions for regulation and competition defense were created, and state enterprises were transferred to private owners or concessionaires.

Government policy was to gradually replace its role as producer and resource allocator by an increasing regulatory role. For this purpose, privatization and concession processes were launched, and regulatory entities were created.

\footnotetext{
${ }^{2}$ Private Investment Promotion Commission.

${ }^{3}$ Special Privatization Committees

${ }^{4}$ National Institute for Competition and Intellectual Property Defense.
} 


\section{(e) The New Foreign Trade Policy}

In 1992, Fujimori carried out a "civil coup" and closed the Congress. The legislative void created by this coup and the already existing climate of liberalization created conditions for the government to remove all the pieces of the protectionist scaffold, to subscribe WTO agreements, to create institutions to regulate free competition, and to decree the necessary rules.

The new foreign trade policy aimed at productive efficiency but it also expected to favor the anti-inflationary strategy and to reinforce public finances. In August 1990, the exchange rate was unified and in September, the first great tariff reduction established only three levels, $15 \%, 25 \%$ and $50 \%$, but maintained the $10 \%$ surcharge for certain items. ${ }^{5}$ The banned imports list was eliminated, and the items subject to a Previous License were reduced from 285 to 13 . The No Competition requirement and the remaining para-tariff restrictions were discontinued, except for sanitary ones.

\section{Table 3. Proportion of Imports covered by the New Tariff Rates, September 1990}

\begin{tabular}{|c|l|c|}
\hline Tariff & \multicolumn{1}{|c|}{ Items } & Proportion \\
\hline $10 \%$ & $\begin{array}{l}\text { Inputs with no domestic substitutes, iron and steel, capital } \\
\text { goods for the industry, metal mechanics, agriculture, } \\
\text { medical equipment, some medicines, CKD packages, } \\
\text { vehicle parts/pieces, tires. }\end{array}$ & $41.3 \%$ \\
\hline $15 \%$ & $\begin{array}{l}\text { Other capital goods, inputs with domestic substitutes, } \\
\text { reduced incidence on production costs, and ad-valorem } \\
\text { rate over 25\%. Agricultural products for final } \\
\text { consumption. }\end{array}$ & $36.9 \%$ \\
\hline $25 \%$ & $\begin{array}{l}\text { Other consumption goods, inputs with tariffs over 50\% } \\
\text { that did not represent an important share of the cost of } \\
\text { other productive activities, capital goods with rates over } \\
50 \% \text { and with domestic substitutes. }\end{array}$ & $21.8 \%$ \\
\hline
\end{tabular}

Source: Carlos Boloña Behr and Javier Illescas Mucha, Políticas Arancelarias en el Peru, 1980-1997 Free Market Economy Institute and San Ignacio de Loyola University, November 1997, Lima, Peru.

The average tariff, including a temporary surcharge, went from 66\% in July 1990 to $32 \%$, and the average dispersion, from 25 to 13 points. The maximum rate dropped from $84 \%$ to $50 \%$ and most exemptions were eliminated. In November, the surcharge was removed, the average tariff falling to $26 \%$, and the subsidy to non-traditional exports was also removed. In December, a schedule for future annual reductions to reach a uniform flat rate of $15 \%$ was published.

5 Carlos Boloña Behr and Javier Illescas Mucha, Políticas Arancelarias en el Perú, 1980-1997, Free Market Economy Institute and San Ignacio de Loyola University, November 1997, Lima, Peru, pp. 52-60. 
In March 1991, the 50\% rate was removed, leaving only two tariff levels, $15 \%$ and $25 \%$. The reform also advanced at the institutional level:

a) The Prior Import License, the No Competition Ruling, the Unified Import Registry, the Andean Group Import Registry and other quantitative restrictions were formally eliminated. ${ }^{6}$

b) The monopolies of state enterprises in food products and inputs were eliminated.

c) INDECOPI ${ }^{7}$ was created as the entity in charge of overseeing free competition.

d) A total reform of Customs was launched with exceptional success. Total revenue, including sales taxes collected at Customs, rose from $23 \%$ of imports to $35.8 \%$ in 1999 , and the average length of the Customs clearance process was reduced from several weeks to 24 - 48 hours.

Additionally, the foreign currency market and the assets account of the balance of payments were freed, and restrictions on foreign currency transactions and holdings were eliminated, including the requirement that exporters sell their foreign currency to the Central Reserve Bank $(B C R)^{8}$ at a the unified exchange market rate $(\mathrm{MUC})^{9}$.

Business pressures channeled through Congress succeeded in abolishing the announced tariff reduction schedule, which was understood as a setback and generated doubts about the continuity of the reform. In this sense, it is evident that the so-called civil coup of 1992 was a determining factor in deepening the reform. In 1995, the official proposal for a flat tariff and the position of some business groups in favor of a tiered tariff motivated a public debate which indefinitely postponed the new tariff changes. From 1993 to June 1998 the reform became deeper through new changes in the tariff structure, with some setbacks. But in all, the average rate fell from 16.3\% in June 1993 to $13.5 \%$ in March 1998.

This ambitious reform sets a milestone in the trade history of the country. Neither the extent of liberalization nor the speed of the change has antecedents in the history of the country.

\section{Antidumping and Safeguards}

\section{A. Institutional Reform}

A great part of the reform was materialized through new laws that regulate aspects of market behavior, such as Monopoly, ${ }^{10}$, Foreign Investment ${ }^{11}$, Consumer Protection ${ }^{12}$, Unfair Competition ${ }^{13}$, Competitiveness of Economic Agents ${ }^{14}$, Micro and Small

\footnotetext{
${ }^{6}$ A relation of these restrictions is presented in Table 2.10, Op.Cit., p. 56.

${ }^{7}$ National Institute for Competition and Intellectual Property Defense

${ }^{8}$ Central Reserve Bank.

${ }^{9}$ Single Exchange Market, official exchange rate.

${ }^{10}$ Legislative Decree 701- Oct 1991

${ }^{11}$ Legislative Decree 662 - Aug 1991

${ }^{12}$ Legislative Decree 716 - Oct 1991

${ }^{13}$ Law 26122

${ }^{14}$ Law 28032
} 
Enterprise Development ${ }^{15}$, Bankruptcy, ${ }^{16}$, Ports $^{17}$, Industrial and Intellectual Property ${ }^{18}$ and others. These laws were designed by new technical and professional staff that had studied abroad during the 1980s, or had graduated from national schools already influenced by market economics. Previously, each of these topics had been the competence of different ministries or state agencies, ITINTEC ${ }^{19}$ being one of them. It became evident that an effective launch of the new policies would only be viable if legal and procedural changes were complemented by a drastic change in administrative institutionality and in the mind-set of the responsible officials, who moreover required not only technical expertise but also a necessary independence from the political power. This criterion was shaped in November 1992 by the law that created INDECOPI to provide the state with a modern and autonomous technical institution, whose main mission would be to promote and arbitrate free competition and market access, and protect intellectual property in its different forms.

\section{INDECOPI}

The military government (1968-1980) created ITINTEC, an agency responsible for trademarks and patents registration, intellectual property protection and the administration of technical quality standards. Its performance was marked by strong bureaucratization $^{20}$, which, in the context of liberalization, led to its dissolution at the end of 1990, paving the way for a new INDECOPI, which started operating in March 1993.

The design and operation of INDECOPI was a novelty in the country. It was based on autonomous Commissions specialized in different aspects of the free market. The core criteria was the clear differentiation of jurisdictional and administrative functions, the high technical level of its professionals and a clearly defined vision of institutional objectives to arbitrate and promote the market economy in Peru, particularly in the areas of competition and intellectual property. The Antidumping and Countervailing Measures Commission created in 1991 in the Ministry of Economy was merged into the new institution.

The organizational structure of INDECOPI responded to the need to give greater autonomy to the functional organs of the Institution, especially to the Commissions.

\footnotetext{
${ }^{15}$ Law 28015

${ }^{16}$ Law 27809

${ }^{17}$ Law 27943

${ }^{18}$ Law 26017

19 Technical Standards and Industrial Technological Research Institute

${ }^{20}$ An anecdote. A company that imported rubber tires requested a Certificate of Technical Standards from Itintec. The company required this certificate to import a lot of 50 tractor tires with special specifications. Throughout the process, inefficient bureaucracy and duplicity of roles required that 25 tires be delivered for inspection. The tires were cut in slices and made unusable. When the certificate was granted for the 50 units, only 25 were left. This illustration could have become a mere anecdote, but the importing company belonged to the new president's in-law family, and this event occurred precisely some months before the agency was dissolved.
} 


\section{Graph 1. INDECOPI - Flowchart*}

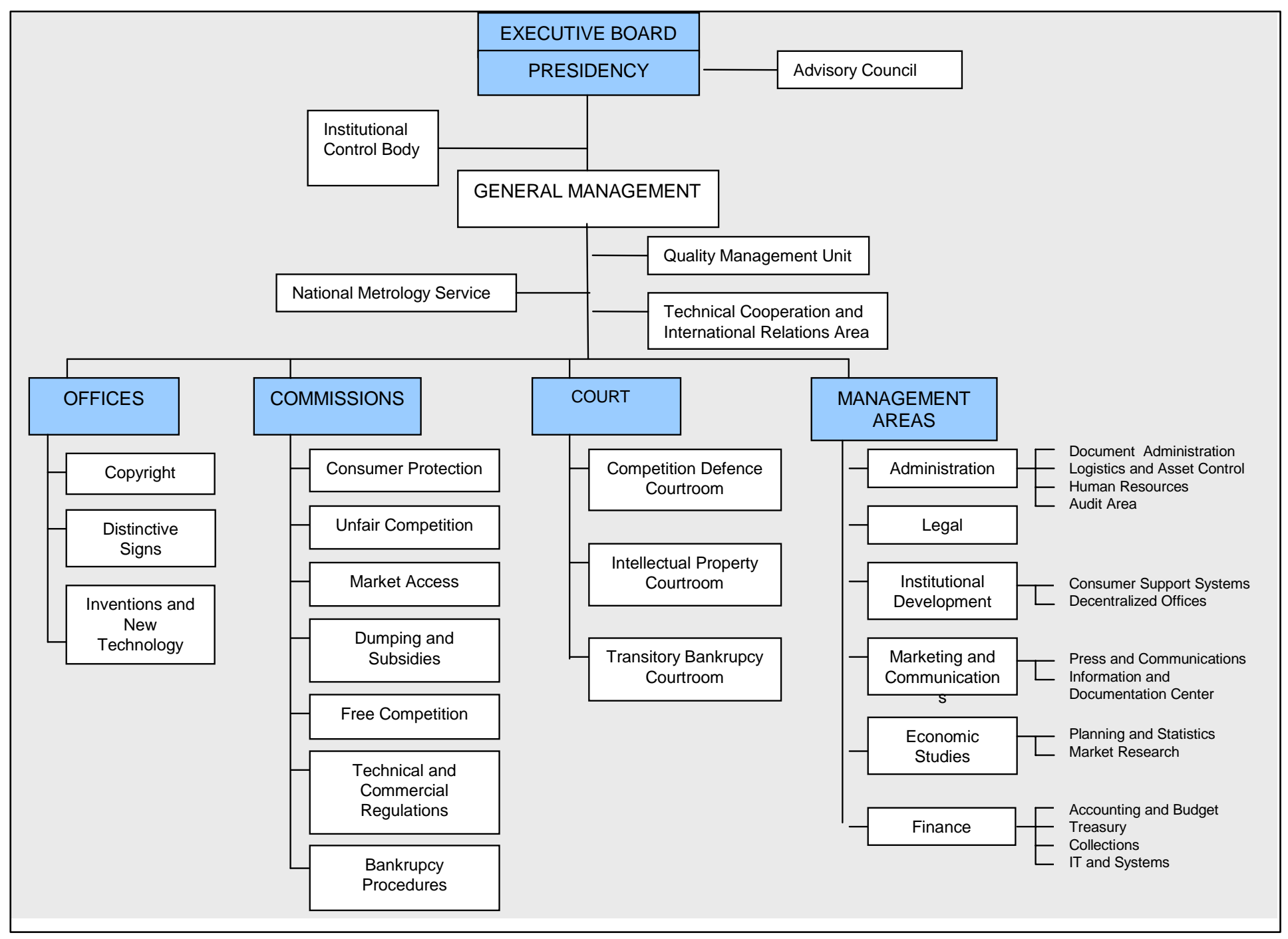


The Executive Board and its president are appointed by the Executive Branch but their activities are independent of it. They establish the general policies of the institution, but they cannot interfere with the decisions of the Commissions.

Each Commission has a Technical Secretariat that channels cases for review, conducts studies and verifies relevant information. They are the technical-economic organs of INDECOPI, which are staffed by full time officials whose analysis is the daily input for the Commissions and for the agenda of the Institution.

The Commissions are collegiate organs. They function as Executive Boards and they meet periodically to review and decide on the issues or cases submitted to them. Their members are not officials of the Institution and their remunerations consist in per diems for the meetings they attend.

Commission members are chosen by the Executive Board of INDECOPI and are renowned professionals and technical experts in each field. They are appointed directly through an INDECOPI Resolution, without government involvement. Commission members do not belong to nor do they respond to nor represent any public agency or institution when they give opinions or vote.

Commission members cannot give opinions or vote in the cases where there is a conflict of interest with one of the parties. Neither are they allowed to hold private meetings with other members of the Commissions. Interviews are held only with the Technical Secretariat or with the Commission in full.

INDECOPI has seven Commissions, which do not interfere with one another. The $\mathrm{CDS}^{21}$, for example, is alone in charge of correcting distortions generated by unfair competition from imported products. However, the reports issued by one Commission can be used as reference for investigations conducted by another.

Commission decisions are expressed through Resolutions that can be appealed before the Competition Defense courtroom of the INDECOPI Tribunal, which is the second administrative instance. The Tribunal is a collegiate organ whose members are proposed by the President of the institution and appointed by the Council of Ministers. Members are selected for technical expertise and, in practice, have been chosen for their professional prestige and political independence. Though Tribunal judgments are based on the same formal criteria used by any court, they are far more expeditious and are based on specialized technical analysis carried out by the Tribunal secretariat.

INDECOPI's budget is financed by revenue from trade mark registrations and renewals and other services (80 \%). The rest is financed by the national budget. Commissions do not have individual budgets. Their expenditure needs are covered by the central administration of the Institution.

Although INDECOPI's budget is not totally independent, the high degree of independence is crucial for the operation of the agency, as it gives it flexibility to hire staff and supports its technical and administrative autonomy. This pattern of technical delegation is part of a general policy that has been evolving in the country.

\footnotetext{
${ }^{21}$ INDECOPI’s Antidumping and Countervailing Measures Commission.
} 
Institutional life, although an example of effectiveness and modernity, has nonetheless been marked by the passage of governments and institutional leaders.

1. From its creation up to 1994 the institution stood out for its staff of young and highly motivated professionals, who applied technical and market criteria and were conscious of their autonomy and commitment to efficiency.

2. Between 1994 and 2001, the institution's leadership and political and public presence stood out. The Commissions continued to work autonomously. It used each Resolution to educate the public regarding market criteria and consumer rights.

3. Since the change of government in 2001 , there has been a continuous struggle to lead the country's most prestigious institution. Its new Board placed emphasis on enterprise insolvency rather than market regulation. Resources and efforts were focused on issues related to dealing with issues of equity restructuring resulting from the 1997 banking crisis and a great number of bankruptcies. The Bankruptcy System Commission was created.

4. At present, in 2004, the institution has a lower profile. For several months the agency operated without a president. This situation was regarded as a lack of interest in competition and market issues by the government. Some recovery in the technical area is evident, although there is less emphasis on promoting free competition.

It is important to recognize the prestige achieved by this institution inside and outside the country. Throughout the changes in its institutional life, INDECOPI has persisted as a service institution, without losing sight of its main goal, the promotion of fair and honest competition. It has become the place for quick resolution of controversies that would otherwise have gone to a judiciary court. Its rulings are respected by the population, which perceives that INDECOPI is not part of the traditional bureaucracy. Conciliation meetings are held daily between unsatisfied buyers and vendors, of electric appliances, for instance. Several focus groups held in Lima revealed that this institution is perceived by the population as "the institution that defends people."

Its presence and the respect of the community spread beyond country borders. In fact, Peru chaired the FTAA Antidumping Commission.

We underline INDECOPI's paradigmatic role is because it hosts the CDS. Undoubtedly, INDECOPI's prestige and authority plays an important role in the acceptance of its decisions.

\section{The Antidumping and Countervailing Measures Commission (CDS)}

The creation of the Antidumping and Countervailing Measures Commission in 1991 grew out of government negotiations with international organizations aimed at reinserting the country into the international financial system. The Commission was born as a collegiate and technical body that reported to the Ministry of Economy and Finance, prior to the effectiveness of WTO agreements on exceptional measures - safeguards or antidumping- contemplated by GATT. It was originally staffed by representatives of the Ministry of Economy and Finance, the Ministry of Industries, the National Society of Industries, and Customs. Only few cases were submitted and their resolution was based on the general guidelines of GATT. However, it became the first instance created to oversee the application of trade liberalization criteria in the country. 
In 1993, the CDS was transferred to the newly created INDECOPI, maintaining its technical approach but also adopting a new style. Its members were no longer representatives of Ministries or of public or private entities, and its autonomy was highlighted. Its line was clearly centered on economic liberalization. In fact, was restrictive in approving antidumping duties. It was in favor of stopping damage but it was against investigation requests aimed at evading competition or getting protectionist support. The Lesser Duty Rule was mandatory applied from 1997 till 2001.

The distinct zeal for economic liberalization and the delayed resolution of the investigations initiated by the Commission, combined with the recent change of government of $2000^{22}$, provoked a campaign by the industrial lobby against the "hard" line of the Commission, and which advocated "more flexible timeframes" and "better treatment" for national producers. This was due to the number of cases declared inadmissible or unfounded as they did not comply with the necessary requirements.

That pressure achieved its goal at the start of Alejandro Toledo's government. In 2001, he was persuaded by the industrial lobby of the need to fight against contraband, subsidies and dumping. This coincided with the change in the presidency of the INDECOPI and with the resignation of all CDS members as a sign of their commitment to economic liberalization and their independence, which were being threatened by political and trade union pressures.

The substitution of all Commission members by others who were mainly linked to the business sector had an inevitable cost in terms of expertise and continuity of criteria. The technical or professional level of investigations was not lost, but the Commission was more influenced by the industrial sector and to some extent this affected the image of impartiality of the institution.

At present, this counter trend has abated and a new emphasis on the "technical" approach is noticeable, half way between the early pro-liberalization view and the proindustry approach of recent years. The current negotiation of a free trade agreement $(T L C)^{23}$ with the United States does not seem to be reflected in the pro-liberalization line of the Commission.

It is evident that institutional design is not sufficient to achieve the goals that motivated its creation, and that the influence of interests in one way or other will always be possible. The important thing to underline is that, with clear objectives and technical criteria, together with carefully selected Commission members, the existing institutionality can guarantee substantial autonomy from political power and private interests.

\section{Legal Rules and Procedures}

Peru's antidumping and safeguards legislation differs in its basics, application criteria and procedures. While the CDS is the competent authority in cases of dumping -it

\footnotetext{
22 The temporary government of Valentín Paniagua, 2000-2001

${ }^{23}$ Free Trade Agreement.
} 
investigates and solves- in the case of safeguards it can only conduct investigations. Then it issues a report on the findings of the analysis performed in each case, but it does not decide on them.

The competent authority to decide whether or not to apply safeguards is the Multisector Commission, formed by the Ministry of Economy and Finance, the Ministry of Industry and the Ministry of Production of the corresponding sector.

This difference is not just procedural. The reason behind the outlined differences is that dumping cases are regarded as the result of practices that create distortions in the market, and should thus be judged on strictly technical criteria. Cases that might justify safeguards, when imports affect domestic industry, are understood as extraordinary situations. These cases require both a technical analysis to determine causes, and a political decision. Domestic production, consumers, other economic sectors and the overall country points of view are taken into account for the application of safeguards.

\section{(a) Antidumping}

Peruvian legislation establishes the same treatment for cases of dumping and countervailing measures based on subsidies granted by the country of origin. In chronological order, the most important rules are the following:

June 1991- Supreme Decree 133-91-EF.- Regulates the criteria and procedures to correct market competition distortions created by cases of dumping and subsidies. This rule takes up the basic concepts of the working groups that designed WTO agreements. It establishes general timeframes without indicating specific ones for each instance of the process. It also authorized the application of provisional duties in any stage of the investigation if injury or threat of injury was determined.

This rule is still in force for cases with countries that have not signed WTO Agreements. It was also applied to cases against WTO signatory countries during the period that went from December 1994, when Peru signed WTO Agreements, until they were regulated in April 1997. It was applied as long as it did not contradict the provisions of the Agreements.

April 1997- Supreme Decree 043-97-EF.- Approves the new Regulation on Dumping and Subsidies for cases against signatory countries of the WTO Agreements.

In general, it takes up the same guidelines and approach of the Agreement. However, the Peruvian rule was more strictly in favor of economic liberalization than the WTO itself. The central criterion was to ensure that the application of duties should not hinder the course of economic liberalization in any way. For example, the minimum dumping margin required to apply duties was raised to $3 \%$ (2\% by the Agreements), and the Lesser Duty Rule became mandatory (in WTO Agreements it is optional). This was a clear effort to prevent the possible use of the mechanism as a way to obtain protection against fair competition. 
When Peru's regulation was reviewed by other countries, they did not make objections, nor did they find any threat against free market criteria ${ }^{24}$. On the contrary, the fact that the same entity was responsible for competition and dumping issues was understood as a sign of respect for competition criteria in the application of antidumping duties.

December 2000. SD 144-2000-EF and SD 225-2001-EF.- Some points in the original regulation (SD-043) are defined. The first one is about timeframes, procedures and qualification criteria for applications. The second one is related to the criteria to qualify a country as a Free Market Economy, to allow the identification of cases in which selling prices in exporting countries cannot be considered normal as they are economies that cannot be qualified as free markets.

January 2003.- SD 006-2003-PCM.-. Replaces the Regulation contained in Decree 043 and its modifications by a new one that consolidates all antidumping and subsidies rules in force into one single legal body. In general, concerning the application of duties, it is less strict than the replaced regulation. It organizes the timeframes to submit applications, changes working days for calendar days and eliminates the mandatory nature of the Lesser Duty Rule.

\footnotetext{
${ }^{24}$ Question-response procedure reported in the WTO web site following the notification of Peru's antidumping regulation in 1998. The questions came from Canada and the European Union and referred to the lesser duty rule.
} 


\section{Graph 2. Antidumping Procedure}

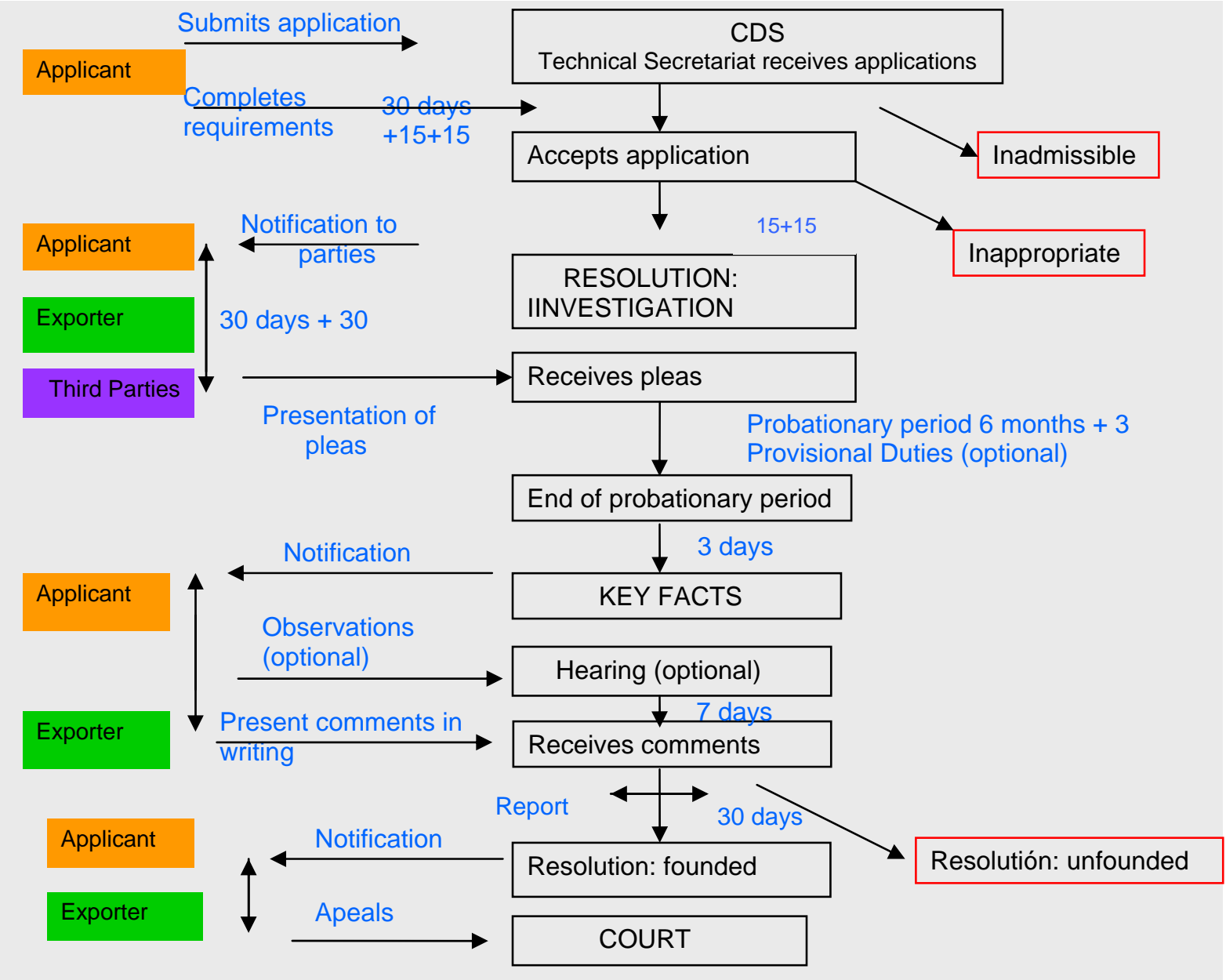

Applicants request an investigation by the Technical Secretariat of the CDS. To do so, they fill out a questionnaire and present supporting documentation on the existence of dumping, the applicant's representativity in the domestic industry, the product that is subject of dumping, the exporting country, the country of origin, producers, known exporters, importers, prices, volumes, the evolution of sales, and all data related to the damage caused.

The Commission is also entitled to initiate an investigation on its own account. To submit an application for a dumping or subsidies investigation, it is necessary to pay the 
equivalent to $80 \%$ of the $\mathrm{UIT}^{25}$, a tax unit that is equivalent to S/. 3,200, approximately US $\$ 925$. This fee is divided into two payments. The first one is made when the application is submitted and it is equivalent to $20 \%$ of the tax unit. The remaining $60 \%$ is paid when an investigation is initiated and only if this happens.

In principle, the information submitted is not confidential. The parties can request the confidentiality of certain information, but they have to justify this request and attach a non-confidential summary of that information.

This stage is followed by a period to complete the preliminary information, after which the competent authority will decide whether the case is accepted for an investigation or not. The timeframes are 30 days and 15 days respectively, but both can be extended for an equivalent period, so this stage can last up to 90 days.

The data submitted by the applying company is used as the basis to start an investigation and it is notified to the parties quoted in the application, who are to make their pleas within the next 30 day period, which can be extended to 60 days.

A probationary period of 6 months extendable to 3 more, follows, allowing the Technical Secretariat to gather and analyze the information available. Before a determination is made, the Commission issues a document containing the Key Facts that will support its final decision. This is notified to the parties so that they can submit their final comments within five days of receiving the notice.

When either party observes the Key Facts report, a final hearing is convoked so they can expose their allegations in writing within the following 7 days.

The timeframe for the Commission's final assessment and decision to apply duties or declare the application unfounded is 30 days. If duties are imposed, they come into effect on the day following the publication of the Commission's Resolution and remain in effect during subsequent appeals. Summing up, the maximum length of the process is 9 months extendable to 12 . All periods are expressed in calendar days.

The detailed written report describing the facts and the analysis performed generated by each case is available to the parities or anyone interested at the INDECOPI website.

The Resolutions of the Commission can be appealed before the Court of INDECOPI, which acts as the second administrative instance. The timeframe for the revocation or confirmation of the appealed is 6 months extendable to 8 . The next option is to take legal action or to make a complaint before the WTO.

\section{(b) Safeguards}

SD 020-98-ITINCl.- The first device that regulates Safeguard Agreements in Peru, jointly with the WTO Agreements on Textiles and Clothing.

\footnotetext{
${ }^{25}$ To date, the Tax Unit is fixed in Soles 4000, equivalent to US\$ 1160.
} 
This rule defines the concepts and procedures for the application of safeguard clauses to cases where the increase in imports affects local industry. It establishes that applicable safeguards will preferably be ad-valorem tariff levies and only in exceptional cases, specific tariff levies or quantitative restrictions. It also establishes the creation of a Multisector Commission, formed by several ministers, as the Competent Authority to decide on the application of safeguards; its decision being based, in each case, on the investigation conducted and the report prepared by INDECOPI's CDS, which behaves as the investigating authority. The decree also establishes a special treatment for the application of safeguards to developing countries that are members of the WTO, demanding that imports of the product reported should represent a minimum 3\% individually or $9 \%$ jointly with other countries over Peruvian imports.

The application of provisional safeguards, which will not exceed 200 days, is authorized for exceptional cases.

In general, this is a restrictive rule that seeks to discourage the use of this mechanism. An example of this is the fact that by regulating the transitional safeguards foreseen in the Textiles and Clothing Agreements, it demands the same requirements as for definitive safeguards.

October-2003- SD 023-2003-MINCETUR.- Regulates transitional safeguards foreseen in the ATV $^{26}$ and transitional safeguards foreseen in China's accession document to the WTO. The rule establishes that applicants must justify that the requested measure will favor the public interest. But the trend is towards more flexible requirements. In fact, a provisional transitional safeguard clause is introduced.

The Technical Secretariat of the CDS, which acts only as an investigating authority, receives the investigation request submitted by the applicant and prepares a report that is presented to the Multisector Commission.

The application includes information about the product, the volume and the evolution of reported imports, and the alleged damage, but must also include an economic report that quantifies the impact of the measure on final and intermediate consumers and on public interest $^{27}$.

In exceptional situations and when the national interest is involved, the authority is also entitled to initiate investigations.

\footnotetext{
${ }^{26}$ WTO Agreement on Textiles and Clothing.

27 Up to recently, consumers were not recognized as Interested Parties. However, a recent decree, Decreto Supremo 017-2004-MINCETUR, modified the procedure and possible affected parties are now notified and invited to present their opinion. The impact report is prepared by Indecopi.
} 


\section{Graph 3. Safeguards Procedure}

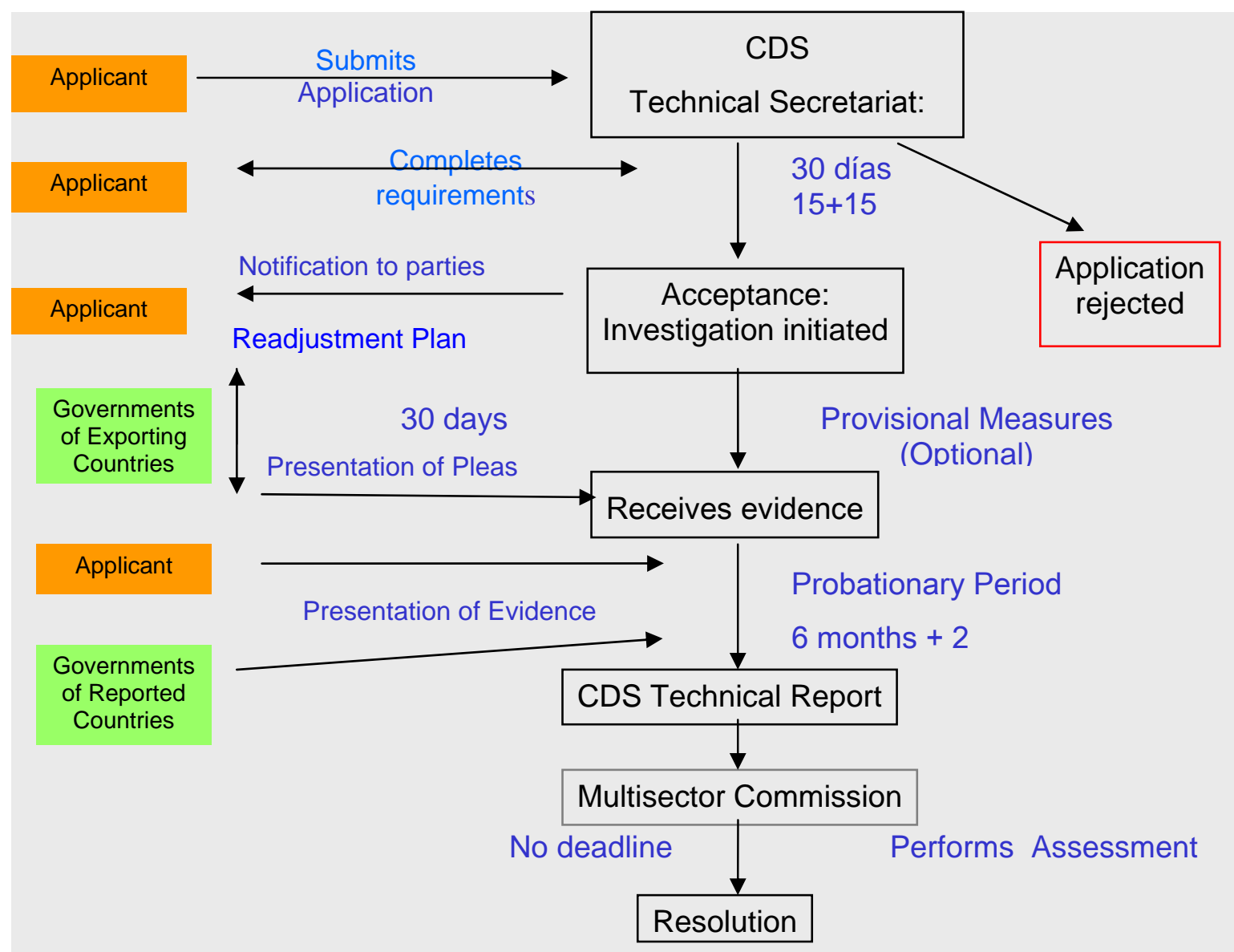

The first part of the process is similar to dumping investigations. The difference is that the applicant must present a Readjustment Plan for the domestic industry within 30 day of the start date of investigations. This plan must explain how the domestic industry is going to adjust to competition created by imports in the medium term.

The probationary period lasts 6 months and can be extended to 8 , and concludes with the technical report issue by the CDS. During this time, consultations with WTO members whose exports might suffer significant damage by the requested safeguards, take place.

There is no limit to the time that the Multisector Commission may take to reach a resolution after receiving the report from the CDS. It may also take the recommendations of the CDS into account or not. In principle, it must assess the general economic interest of the country, the effects of the measure at the national level and with respect to the 
trade relations with countries that will eventually be affected, especially if Peru's consolidated tariff level in the WTO of $30 \%$, is surpassed.

If safeguards are applied, they will be in force for three years extendable to three more. This timeframe is shorter than the eight-year period allowed by GATT rules. In summary, the decision to apply safeguards has much more political room for maneuvering than decisions about antidumping.

\section{Other Aspects of Peru's Experience}

Information Available.- Sources from the investigating authority and from the users of the mechanisms coincide that one of the hindrances to the agility of dumping investigations is the lack of availability of complete statistical data. While Customs statistics are available, information concerning production statistics is less accurate and in some cases the data available in ministries of production is incomplete, outdated and unreliable. Data verification consumes valuable time and effort by the Commission, which often must decide on the basis of the best information available.

Application Costs.- The use of advisors is not a formal requirement to submit an application for a dumping or safeguards investigation. In practice, companies tend to commission the preparation of their cases to law firms or economists specialized in this field, not only to submit the file but also to closely track its evolution. It is estimated that on average, these specialists charge a fee that ranges from US $\$ 10,000$ to 15,000 per case.

However, there are also companies that do not resort to external services to support their cases. In 1999, a small company managed to get provisional duties applied, and later definitive ones of $120 \%$ and $734 \%$ for dumping caused by imports of "bodyboards" for surfing and recreation, "kickboards" for swimming pools and fins from the People's Republic of China and Taiwan. The company was able to support every point on its application, even opposing China's claim to be treated as a free market economy.

A particular aspect of Peru's procedure is the fee paid by the company for submitting an investigation application. Compared to other countries where this process is free, charging a fee could be regarded as a barrier to making applications. However, the amount fixed at $80 \%$ of a UIT, equivalent to US\$ 925 to date, is very low. The businessmen contacted have said that they agree with the fee, and some even said they were in favor of charging a fee, as a way of "contributing" to the costs of investigation. An anecdotic case is that of a businessman who, when interviewed on this topic, said that if he did not win the case, he would at least get a useful study on his product at very low cost.

Representativeness of the applying company.- Both the Agreement and the Regulation are based on the criteria that applicants should represent at least $25 \%$ of the domestic industry affected. Peruvian legislators have preferred to keep this minimum level as they understand that raising it would give an advantage to large companies.

Elusion of Duties.- Elusion cases that wrongly specify the tariff item, or origin or other technical description of the product, can be reported by the applicant or by a CDS selfinitiated investigation. This entity must ensure that the imported product that has been penalized with antidumping duties pays them independently of the tariff item through 
which it enters the country. However, controlling the right item and collecting its revenue is a Customs task. The new law for Customs crimes establishes imprisonment for economic agents who try to elude antidumping duties by faking product information, and for Customs officials who do collude in such elusion.

Budget for Commissions.- Commissions have tight budgets. Although so far these bodies have been able to conduct investigations in a reasonable way, the lack of resources of the technical secretariat is notorious. The timeframes and technical rigor of reports could improve with adequate resources, for example, by the ability to hire specialized studies. When a neighboring country is involved, a member of the Technical Secretariat might travel to conduct in situ investigations.

Public Interest in Peruvian Rules.- In the specific case of safeguards, point 10 of Article 8 of SD 020 requires that applications should include an "economic report that quantifies the impact of the measure on final and intermediate consumers and on the public interest". Accordingly to the recently issued Supreme Decree 017-2004-MINCETUR), potentially affected parties are invited to submit their points of view.

In the case of antidumping measures, when imports come from countries that are not members of the WTO, Article $17^{\circ}$ of SD.133 indicates that to the extent possible, the Commission should gather, "opinions from buyers and/or users of the product that is subject of an investigation application." In the case of imports from countries that are WTO members, Article $23^{\circ}$ of SD 006 entitles the Commission to initiate self-imposed investigations when the "national interest is involved." However, the consideration of the "national interest" is not necessary when analyzing the convenience of applying antidumping duties, as it is understood that when correcting distortions generated by unfair practices the authority is acting in favor of free competition and therefore, public interest.

Transparency of information.- The applications, the questionnaires that the parties fill out, the key facts of a case, the hearings, and the reports of the Commission are all open documents. The rule establishes that a company can request that information that is considered confidential should not be disclosed, provided a non-confidential summary of that information is attached. The reports prepared by the Commission are detailed; they record the facts, the findings of the analyses conducted and the considerations that are taken into account for the decision that is made. Reports are published in the INDECOPI website so that the public can have access to them. The public nature of the information is meant to be consistent with a free competition scheme, and it is not aimed at discouraging applications, although in some cases it can have that inevitable effect.

Dissemination of Mechanisms.- Antidumping and safeguards mechanisms available are not as familiar to the business sector as would be desirable. INDECOPI, mainly through the CDS, has made efforts to disseminate the criteria on which trade defense mechanisms are based, to assist companies as possible applicants but also to defend them should claims against their exports be made by other countries. The National Society of Industries also has a department in charge of antidumping and subsidy issues, which coordinates activities for its members, but it is not very active. Other efforts to inform have included meetings, round tables and conferences, but these have been sporadic. This explains the scarce use of the mechanism to date, and that the growing flow of cases is directly related to the learning process of the business sector. 
So far, the best way to disseminate the mechanisms and their scope has been through the businessmen who have presented cases, the advisors who have studied the cases, former officials and other related professionals, who are generating a considerable degree of maturity and knowledge in the private sector.

Inter-agency Support.- There is no Inter-agency cooperation in formal or regular terms. During some phases of the CDS, there has been informal but close cooperation with Mexico's SECOFI. Authorities say that their cooperation needs are channeled through Peru's trade delegations abroad, especially in Geneva and the WTO. A frequent complaint is that formal foreign cooperation does not always reach investigating authorities, because the formal channels that should be used constitute a limitation and sometimes cooperation is wrongly channeled.

\section{B. Peru's Cases}

\section{Overall Results}

(a) Outcomes of Investigation Applications

A total of 81 trade defense applications were submitted to the CDS since it was created in 1999 until now . Most (70) correspond to cases of alleged dumping; 7 were claims for subsidies, and only 4 were requests for safeguard clauses. Of the total, one out of four applications (21\%) was considered inappropriate or was withdrawn by the applicant, and therefore an investigation was not initiated.

Table 4. Applications and Measures, 1993-2004

\begin{tabular}{|l|c|c|c|c|}
\hline & Total & Subsidies & Safeguard & Dumping \\
\hline Applications & 81 & 7 & 4 & 70 \\
\hline Investigations & 64 & 5 & 2 & 57 \\
\hline Provisional Duty & 30 & 3 & 1 & 26 \\
\hline Provisional and Founded & 23 & 2 & & 21 \\
\hline Founded & 28 & 2 & & 26 \\
\hline Partially founded & 4 & 1 & & 3 \\
\hline Unfounded & 28 & 2 & 1 & 25 \\
\hline Pending Resolution & 4 & & 1 & 3 \\
\hline
\end{tabular}

Source: INDECOPI

Note: Two cases that were presented but subsequently withdrawn by the petitioner are included in the total for Unfounded Cases.

Of the 64 applications admitted for an investigation, two were withdrawn by the applicants. Provisional duties were applied in 30 cases, of which 26 were dumping cases. Of the latter, 21 eventually led to definitive duties and 5 were declared unfounded. 
Of the 70 applications for dumping cases, 29 were considered totally or partially founded at the end of the investigation and deserved definitive duties.

Investigations undertaken at CDS initiative have been few. They consist of one case against Indonesia, regarding shoes, and three cases against China, regarding clothing, shoes and water meters. As a rule, the Commission tends to consider that the damage must be proved by the applicant whenever possible.

(b) Incidence over time

Graph 4 shows a marked increase in the number of applications submitted and applications approved over time.

\section{Graph 4.}

Investigations and antidumping duties in Peru, 1993 - July 2004

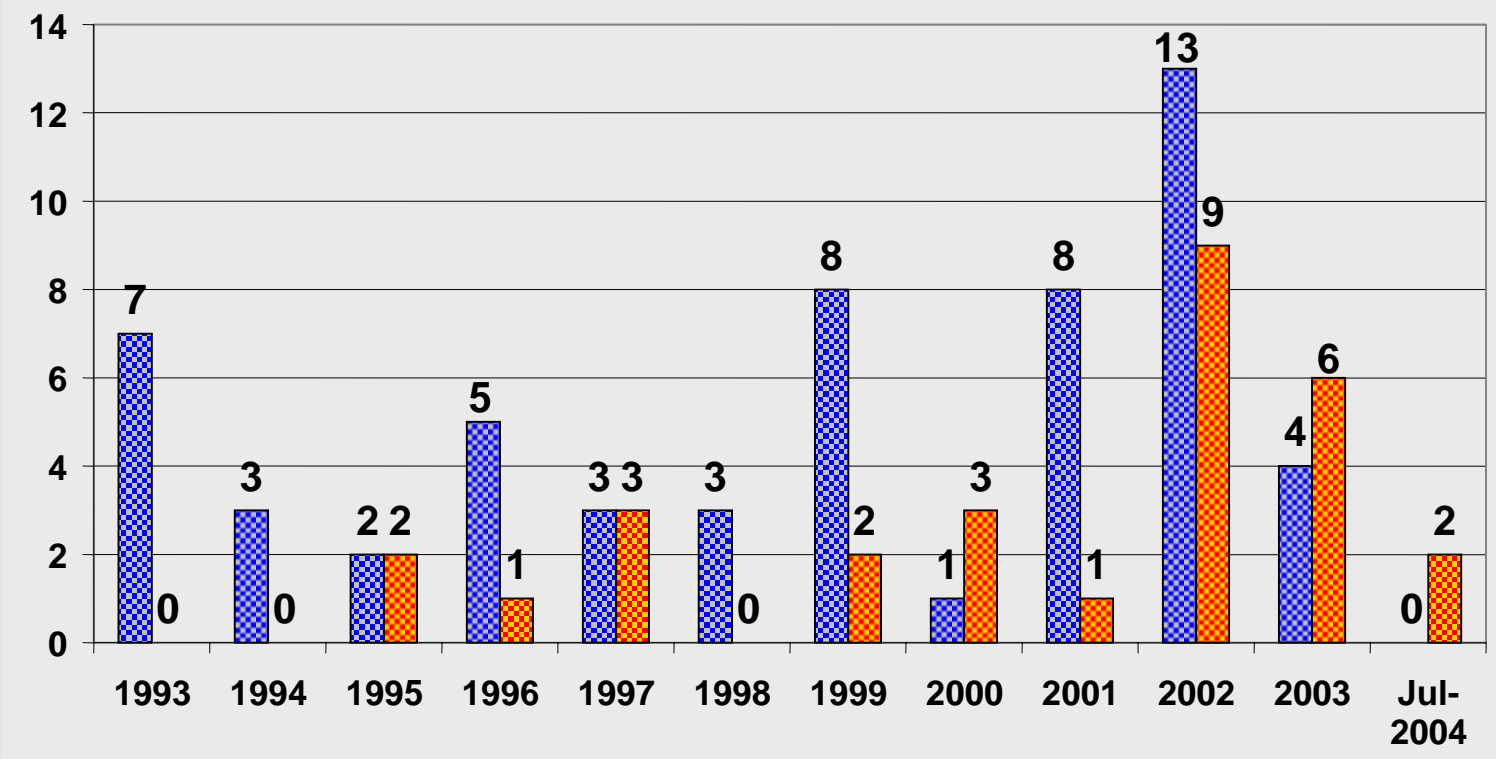

圆 Investigations : Antidumping duty

The average number of 3.8 cases per year submitted during the first six years, 1993-1998, rose to 6.2 in the following five and a half years (1999 to July 2004). The increase in the number of applications that were declared founded was even more significant - rising from 
1.3 per year between 1993 and 1999 to 4.2 per year as from 1999 (the second comparison period - 1993 to 1999 - starts a year later to allow for the time required to decide on each petition).

According to a recent survey (June 2003) conducted by the National Society of Industries, $77 \%$ of industrial companies that have faced some form of unfair foreign competition consider that they were affected by dumping practices, and $20 \%$ by subsidies.

Surprisingly,, only less than $5 \%$ of these companies have submitted applications to the CDS

The authors believe that the limited use of these mechanisms registered during the first years, and the increasing volume of cases submitted for the most part reflects a gradual learning process by companies. Conversely, in countries such as Mexico or Argentina, we see that the number of cases has started to decline. A learning process is also taking place with exporters. In the long term, trade defense measures have the effect of discouraging unfair trade practices.

An increase in the average number of investigations initiated is also observed. It rose from 4.7 cases per year (28 in 5 years) during the first period, to 6.4 per year (32 in 5 years) in the second one. The increase coincides with the political change that took place beginning in 2000 , when Valentín Paniagua was sworn in as interim president and succeeded by the current government of Alejandro Toledo in 2001. Of these investigations, antidumping duties were applied to 9 cases in the first 5 years (1.5 per year), while in the second stage, this figure rose to 21 cases in 5 years (4.2 per year ).

In percentage terms, investigations considered founded grew from $32 \%$ in the period 1993-2000 to $66 \%$ over $2001-2003$.

\section{(c) Incidence by Sectors}

In terms of sectors, the use of the antidumping mechanism has been diversified. Sixteen different activities requested trade defense measures, eight of which submitted three or more applications. This diversified pattern has not varied significantly between the early period 1993 - 1998 and the most recent period, the most frequent user being the iron and steel sector, with $18 \%$ of total cases. Likewise, agriculture, textiles and meters (electricity and water) represent $11 \%$ of the total each, while chemical products have a $9 \%$ share. 


\begin{tabular}{|l|r|r|r|}
\hline Sector & \multicolumn{1}{|l|}{ Total } & \multicolumn{1}{l|}{ 1993-98 } & \multicolumn{1}{l|}{ 1999-2003 } \\
\hline Agriculture & 6 & 2 & 4 \\
\hline Iron and Steel & 10 & 4 & 6 \\
\hline Tires & 3 & 2 & 1 \\
\hline Textile & 6 & 3 & 3 \\
\hline Meters & 8 & 5 & 3 \\
\hline Shoes & 3 & 1 & 2 \\
\hline Chemicals & 5 & 2 & 3 \\
\hline Others & 16 & 7 & 9 \\
\hline Total & 57 & 26 & 31 \\
\hline
\end{tabular}

Source: INDECOPI

Agricultural cases are only six. This scarce use of defense mechanisms must not be seen as an absence of unfair practices in agriculture but as a result of the composition of the sector in Peru. It is mostly composed of small and medium size farms which lack the organizational or management capacity to prepare an antidumping case. A group of cotton producers, for instance, expressed their interest in presenting a dumping case but they did not submit an application requesting that the Commission initiate an investigation on its own account, and arguing that they lacked the necessary management capacity. However, Commission policy is that affected producers must provide proof of damage themselves and be involved in the process.

\section{(d) Incidence by Country}

\begin{tabular}{|l|l|l|l|l|}
\hline \multicolumn{5}{|c|}{ Table 6. Antidumping Investigations by Country } \\
\cline { 2 - 6 } & Total & Dumping & Subsidies & Safeguards \\
\hline China & 20 & 19 & & 1 \\
\hline $\begin{array}{l}\text { Other Asian } \\
\text { Countries }\end{array}$ & 7 & 7 & & \\
\hline Chile & 11 & 11 & & \\
\hline Argentina & 9 & 7 & 2 & \\
\hline Brazil & 6 & 5 & 1 & \\
\hline $\begin{array}{l}\text { Colombia- } \\
\text { Venezuela-Bolivia }\end{array}$ & 4 & 4 & & \\
\hline Mexico & 3 & 3 & 1 & \\
\hline Europe & 2 & 1 & 1 & \\
\hline Non-WTO & 7 & 6 & 1 & \\
\hline Others & 2 & 1 & & \\
\hline
\end{tabular}

Source: INDECOPI

Note: some cases are recorded in more than one country and therefore, sums differ from other tables. 
The incidence of antidumping investigations by country of origin of imports shows that the main country reported was the People's Republic of China with $26 \%$ of total cases. Most imports of Chinese origin are textiles, clothing and water meters, and to a lesser extent stainless steel cutlery and pans, tires, zippers, pottery and iron hinges. Of total applications against China, only three cases were declared unfounded, one because the product reported was not similar to the product manufactured in the country and another one because the cause of damage disappeared. Peru does not apply the Most Favored Nation clause to imports from China.

Chile is in second place with $17 \%$ of the total, a frequency that is explained by the existence of the Bilateral Trade Agreement which does not include dumping clauses. Argentina is third with $11 \%$ of the total.

Likewise, the figures on antidumping investigations that led to definitive duties show a similar pattern of incidence by country; the People's Republic of China represents 32\% of the total, while Chile has a 19\% share. Most investigations initiated against Argentina did not lead to the application of antidumping duties, and its share is thus only $4 \%$. On the other hand, of total investigations initiated against those three countries, $64 \%, 56 \%$ and $17 \%$ respectively, led to the application of antidumping duties.

\section{(e) Average Length of Processes}

The average delay for the resolution of cases has varied over time. For safeguard and antidumping duty applications, from presentation of the request to the final resolution, the delay has been 9.5 months on average, without including appeals. This figure increased slightly, from 8.4 months for cases presented between 1993 and 1996 to 10 months for cases presented since 2001, with the exception of those that received provisional duties, in which case the waiting time was shorter.

Although some sources interviewed say that timeframes have become shorter, this is not reflected in the data. There are still petitions that go through an eight-month decision process and others that delay 12 months. Although a dumping or safeguard investigation requires a certain amount of time to get reliable results, there is no consensus as to the most desirable length for processes. Investigators who are former members of Commissions believe that extended processes are not only part of the technical investigation of reported cases but also discourage the unnecessary presentation of applications.

\section{(f) Andean Community Cases}

WTO Agreements state that dumping or safeguard cases between countries that are signatory of bilateral or multilateral agreements may be solved within the context of such agreements. As Peru is a signatory member of the Andean Community, the applications for investigations against imports from countries that are also members must be presented before the General Secretariat of the CAN (Andean Community), pursuant to Decision 456. 
Five cases has been presented by Peruvian producers before the CAN in the last 10 years, $6 \%$ of total applications received by the CDS. The figure might seem low but it is proportional to the low volume of Peruvian imports from CAN countries, which in 2002 represented $8 \%$ of total imports. At present, some cases remain unresolved, such as the case of edible vegetable butter presented by Peru against Colombia.

In the CAN, the investigation is carried out by the authorities in charge of the integration process within the Andean market. Applications for dumping or safeguards could therefore be perceived as an obstacle to the integration process, which is the CAN's overriding priority.

Between 1998 and 1999, Peru was invited by its partners to adopt community safeguard and antidumping policies against third parties. Peru chose to keep its individual regime.

\section{(g) Safeguard Cases}

Only four investigation applications for safeguard duties have been presented in Peru. Two of them were declared inappropriate and only two deserved an investigation. One of them was initiated on May 11, 1999 by Siderperú, an iron company, which requested the application of safeguards on hot-rolled and cold-rolled steel sheets and coils, and construction steel bars from countries that are not members of the WTO. The CDS investigated the case and presented a favorable report to the Multisector Commission. However, this body never met to make a decision, and thus the political decision not to apply these measures became evident by default. Seven months later the company presented a dumping case for the same products. In December 1999, definitive antidumping duties over the same imports from Ukraine and Russia were approved at the request of SIDERPERU.

The other safeguard case concerns clothing from China. It was presented in October 2003 and will be described later on.

\section{(h) Appeals}

The Competition Defense Courtroom of INDECOPI's Court is the second administrative instance and it hears appeals presented by the parties in the processes followed before any of INDECOPI's Commissions. Of the 81 cases reviewed by the CDS, 34 were appealed, of which 30 corresponded to dumping cases and one to safeguards. This represents $7 \%$ of the total cases received by the Court.

According to the data available, of 30 dumping appeals, the Court confirmed the CDS determination in nearly $90 \%$ of the cases. There are three cases in which the appeal has been revoked or returned to be modified, and there are four cases with pending resolutions. 


\section{Some Cases}

\section{A. Cast Steel Balls: Chile}

- In February 2000 a Peruvian company, which we will call Acme Peru, that manufactures $50 \%$ of the domestic production of cast steel balls for metallic mineral grinding requested an investigation to the CDS against imports from a Chilean company, which we will call Monarch Chile, on the grounds of suspected dumping practices.

- In July 2000 , the company that manufactures the remaining $50 \%$ of the domestic production -in this case forged steel balls- here called Steelco Peru, formally appeared in the process and opposed the investigation request, indicating that it was not affected by Chilean imports.

- In 1998 Peru and Chile had signed an Economic Complementation Agreement to form a Free Trade zone, and established duty-free schedules for several products. Steel balls for mineral grinding were exonerated from tariff payments as from the second semester of 1998.

- As from 1999, the volume and share of Chilean steel balls in the Peruvian market increased from 200 metric tons to 7000 - 8000 metric tones in 2000.

- Having completed the investigation and proved the dumping and its relation to the damage caused, in March 2001 the CDS imposed definitive ad valorem FOB duties of $11.05 \%$.

Parallel to the Peruvian investigation, in Chile a local company, Acme Chile, presented a dumping investigation request against Peruvian imports of the same product - steel balls manufactured and exported by Steelco Peru.

The Peruvian and Chilean companies that submitted the applications are business partners with the same name. They have a corporate agreement by which the Peruvian company cannot export to Chile and vice versa. The aim of this joint strategy was to consolidate their positions in the local markets through parallel applications against their main competitors, thus neutralizing the recent Trade Agreement between both countries, which established mutual tariff exonerations for this product.

The corporate objective of the Peruvian producer and its Chilean partner succeeded only partially. Peru applied an 11\% antidumping duty while Chile turned down the application against the Peruvian exporter.

\section{B. Cornstarch and Glucose Syrup: Mexico}

- On May 10, 1996, the CDS initiated an investigation of suspected dumping in cornstarch and glucose syrup imports from Mexico.

- The Mexican company accepted the dumping charges and requested a price undertaking which was refused by the Commission.

- Given the significant increase of imports recorded two months after the investigation was initiated, provisional duties of $9.51 \%$ were applied for cornstarch and of $14.68 \%$ for glucose syrup. When the investigation was over, 
definitive duties were fixed. The Mexican company appealed but the Court confirmed the Resolution of the Commission in August 1997.

- Two years later, the Mexican company requested a new investigation to leave without effect the antidumping duties that had been applied. This action led to the reduction of duties on glucose syrup to $3.32 \%$.

This case was the first one in which a revision of duties was requested on the basis of a change of circumstances. The process was favorable to the exporting company in relation to one of its products.

In addition, the case resulted in a Commission policy of not accepting price undertakings, considering that the effect, which would be the same as for the application of antidumping duties, would not justify the effort and logistics necessary to track and inspect accordingly. Instead, antidumping duties are controlled by Customs, they are fiscal revenue, and do not require supervision by the Commission.

Although Peruvian law contemplates price undertakings, the Commission interpreted it as an option and not as an obligation, choosing to restrict them to inevitable cases, as for example, when instead of being proposed by the exporter or its government, price undertakings are agreed by the parties as a way to suspend the investigation.

\section{Textile Clothing: China}

- In October 2003, the Society of Industries requested that the CDS carry out a safeguard investigation against textile clothing products of Chinese origin, due to the extraordinary increase in their volume.

- The Commission conducted a study of 288 items of clothing, towels, bed sheets and bed linen, and identified 106 which represented the main quantity of Chinese imports into Peru at present. Safeguard measures were to be applied to these imports.

- China's protocol of accession to the WTO established a Specific Product Transitional Safeguard mechanism, which contains a clause that allows for the imposition of provisional safeguards. For this mechanism to be applied, it must be proved that the reported imports cause or threaten to cause disruption in the domestic industry.

- In November 2003, only one month after the investigation was initiated, the INDECOPI's Antidumping and Countervailing Measures Commission report concluded that conditions for an immediate application of provisional transitional safeguards to Chinese textile clothing articles had been met, and that if these measures were not taken, the domestic industry that supplies the local market would suffer an injury that would be very difficult to repair.

- The Commission also recommended that Customs take adequate control measures to avoid evasion of the possible duties to be applied, through migration of items or contraband. It also recommended that the Ministry of Production and the interested economic agents be alert for any increase in the imported volume of items that were not affected, so as to take new measures as soon as possible. 
- The report was presented to the Multisector Commission. On December 5, 2003 provisional safeguards to Chinese textile clothing articles were applied for an effective period of 200 days.

The hidden protectionist interests of the liberal period of the last decade had reappeared, taking advantage of the fall in popularity of Fujimori's government, in an attempt to identify the elimination of protectionist barriers in Peru among the excesses of his government. The local textile industry, pressed by massive and frustrating competition from China, served as a scenario for these appearances.

Although they had the option to present a dumping application and they knew that dumping would be easy to prove, some industrial sectors - part of the textile industry joined by small and medium size clothing manufacturers - chose the course that offered them the greatest margin of trade union and political pressure, and pressed the government for the more political and drastic measure of safeguards, since they refused to assume the effort and costs of an antidumping investigation.

The pressure on the government channeled through the Ministry of Production sought to create the image that all unfair competition in the textile clothing sector came from China. In a highly political context and with unprecedented swiftness, safeguard measures were imposed.

In June 2004, when the effective period of 200 calendar days was about to expire, an open political battle broke out between pro-safeguards groups, textile and clothing companies, and anti-safeguard groups, especially exporters with important Chinese clients and the Embassy of China in Peru. The battle involved the media, government sectors, Congress and public opinion. The debate centered on whether possible retaliation by China on Peruvian exports to that country could be more harmful than the damage caused by Chinese textile clothing imports.

After many years, protectionist interests were seen to be maneuvering in the media as well as in street demonstrations by textile clothing manufacturers in front of Congress. And for the first time there was a debate where neither the damage nor the right to exercise trade defense was discussed. The argument was between those who opposed safeguards and demanded that the issue should be settled through a technical antidumping investigation, which would not constitute a protectionist measure, and those who insisted on political support for the industry, defending the use of safeguards as a traditional protectionist measure.

At the time of writing this report, the government's position on the safeguards was not clear. The most recent decision was to eliminate provisional transitional safeguards to avoid trade retaliation from China, and to adopt provisional general safeguards instead. But the new countries affected by that decision are likely to apply countervailing measures.

Peru's legal and institutional system has worked to the extent that protectionist pressure for the immediate application of general safeguards was avoided. But in the long term, the operation of the system will depend on the capacity of governments to define a course in the face of inevitable pressures. 


\section{Conclusions}

1. The creation of the current antidumping and safeguards system (AD-SG) between 1990 and 1993 in Peru must be understood within the context of a long historical process in which there have been pendular changes between protection and liberalization. However, the current context of strong globalization and the gradual consolidation of a market culture in the country suggest the probability of an "end of story," and that most of the current system will last.

2. The rules and institutions of the current AD-SG system were conceived as part of an ambitious reform package applied from 1990 and aimed at liberalization and the promotion of competition. The current system was designed prior to and independently of the Uruguay Round of the WTO. Likewise, neither the design nor the application of the system has been influenced by exchange rate fluctuations.

3. Both the design and the staffing of the institutions in the system have strongly reflected the principles of technical autonomy, low level of political capture and belief in the market.

4. There is a clear differentiation between unfair competition and dumping on the one hand, and damage and safeguards on the other, applying strict technical criteria to the former and an openly political decision to the latter.

5. Nevertheless, there are various indicators of a partial retreat from the principles of non-political interference and liberalization, especially since 2000.

6. Peru's experience suggests that the WTO should place a greater priority on institutional monitoring in countries such as Peru, including the certification of its institutional processes, and an insistence that the operation of the system be adequately financed.

\section{Bibliography}

Roberto Abusada, Javier Illescas, Sara Taboada, Integrando el Perú al Mundo, University of the Pacific and Peruvian Economy Institute, Lima, 2001.

Alberto Pascó-Font, Jaime Saavedra, Reformas Estructurales y Bienestar, Una Mirada al Perú de los Noventa, GRADE, Lima 2001.

Carlos Boloña, Javier Illescas, Políticas Arancelarias en el Perú, 1980-1997, Free Market Economy Institute, University of San Ignacio de Loyola, Lima 1997.

Roberto Abusada, Fritz Du Bois, Eduardo Morón, José Valderrama, La Reforma Incompleta, University of the Pacific, Peruvian Economy Institute, Lima, 2000. 
Mercedes Araoz, Antidumping and Competition Policy: The Peruvian Experience, University of the Pacific, Conference on "Integrating the Americas", November 20-21, 2002.

Michael Finger, "Antidumping and anti-subsidy measures," in J.M.Finger and A.Olechowski (eds), The Uruguay Round: A Handbook for the Multilateral Trade Negotiations, World Bank, Washington, D.C., 1987.

Michael Finger (ed.), Antidumping - How it Works and Who Gets Hurt, University of Michigan, Ann Arbor, 1993.

Beatriz Boza (ed.), Peru's Experience in Market Regulatory Reform, 1993-1998, INDECOPI, Lima, 1998.

Carol Wise, Reinventando el Estado: estrategia económica y cambio institucional en el Perú, University of the Pacific, Lima, 2003. 